\title{
Elevation modulates the phenotypic responses to light of four co-occurring Pyrenean forest tree species
}

\author{
Lluís Coll ${ }^{1,2}$ (D) Aitor Ameztegui ${ }^{1,2}$
}

Received: 7 September 2018 / Accepted: 28 March 2019 / Published online: 23 April 2019

(C) INRA and Springer-Verlag France SAS, part of Springer Nature 2019

\begin{abstract}
- Key message Elevation markedly modified the species-specific phenotypic responses of trees to light. The effects from elevation mostly occurred at organ level (SLA) for the montane species, but at whole-plant level (allocation traits) for the subalpine ones. The subalpine species allocate more carbon to roots under closed canopies at low elevation. Contrary to expectations, most species displayed smaller specific leaf area at high elevation. The most drought-intolerant species was more severely affected by drought under shade than in open microsites.

- Context Understanding the phenotypic responses of mountain tree species to different levels of local irradiance can be of critical importance for elucidating their capacity to relocate above their current distributional limit in response to environmental changes. - Aims To evaluate whether the response of different co-occurring forest tree species to local irradiance varies when they are growing at various elevations or beyond their current distributional limit.

- Methods Seedlings of four tree species (Betula pendula Roth., Pinus sylvestris L., Abies alba Mill., and Pinus uncinata Ram. ex DC.) were planted under different irradiance levels (forest understory vs natural gaps) and at various elevation (montane-subalpine ecotone and subalpine belt). After four growing seasons, 48 plants per species were excavated to assess allocational (biomass distribution) and morphological (specific leaf area) traits. Midday leaf water potential was recorded during a period of intense drought.

- Results The subalpine species (A. alba and P. uncinata) increased their allocation to the root system at low elevation and under dense canopy. We observed constant or higher SLA in all species when they develop in the subalpine belt. B. pendula was affected more severely by drought at low elevations and under shade than in open microsites.

- Conclusion We found marked species-specific phenotypic variability of tree seedlings to increasing irradiance, with these responses modulated by the elevation at which the trees were growing.
\end{abstract}

Keywords Phenotypic variability $\cdot$ Elevation gradients $\cdot$ Light responses $\cdot$ Allocation $\cdot$ Specific leaf area $\cdot$ Mountain forests

\section{Introduction}

Forest ecotones have been widely used to study the response of vegetation to changes in climate (Hufkens et al. 2009).

Handling Editor: Erwin Dreyer

Contribution of the co-authors

Both authors designed the experiment and collected data in the field. AA analyzed the data. LC took the lead in writing the manuscript.

Lluís Coll

1luis.coll@ctfc.cat

1 Department of Agriculture and Forest Engineering (EAGROF), University of Lleida, 25198 Lleida, Spain

2 Joint Research Unit CTFC - AGROTECNIO, 25280 Solsona, Spain
Most research on forest ecotone dynamics has focused on treeline areas, where the limit of the forest is generally defined by temperature and thus easier to detect and monitor (Kupfer and Cairns 1996; Camarero and Gutierrez 2002; Camarero et al. 2006). Increasing attention has recently been devoted to the dynamics of transition areas between different tree populations (Berger et al. 2007; Benavides et al. 2013; Dinca et al. 2017). In the montane-subalpine ecotone, for example, not only has upward displacement of montane species been observed to track climate warming (Peñuelas and Boada 2003; Lenoir et al. 2008) but also downslope movements of the subalpine species into the montane belt (Hättenschwiler and Körner 1995; Lenoir et al. 2008; Bodin et al. 2013). These different responses are the consequence of critical interactions between changing climate and a number of factors operating at various organizational levels and spatio-temporal scales. Some of 
these factors relate to the physical environment (e.g., topographic variables, edaphic characteristics) or to the influence of biotic agents (pests and pathogens, browsers) (Van der Putten et al. 2010; Ameztegui and Coll 2015). Others are intrinsic to the species and populations, such as their capacity to adapt to changes via demographic processes (e.g., seed production, dispersion, survival-growth trade-offs), (Lloret et al. 2012; Benavides et al. 2015) or their ability to compete for resources (Loehle 2000, 2003; MacArthur 1984). In these cases, differences among coexisting species in their phenotypic responses to the various limiting factors can be decisive factors in the dynamics of transitional areas (Bradshaw 1965; Lloret et al. 2012; Ameztegui et al. 2015).

In the Pyrenean range, where forests have experienced significant densification and canopy closure in the last decades (Ameztegui et al. 2010), the capacity of species to adjust their morphology and physiology to light will be a determinant for future demographical processes in the area (Ameztegui and Coll 2011). It is well-known that the response of species to light varies throughout the developmental stages of plants (Delagrange et al. 2004) and that this response is modulated by the availability of other primary resources, such as water (Sánchez-Gómez et al. 2006) or nutrients (Vernay et al. 2018). There is much less knowledge on whether the capacity of species to modify their form and function in response to light is maintained when they grow at the limits of, or even beyond, their current distributional ranges. However, this processi.e., the interplay between simultaneous phenotypic responses to light and climate — can be of critical importance in defining potential displacements of mountain species in response to environmental changes (Bodin et al. 2013).

In this study, we set up a field experiment in the Pyrenees in which the four most widespread species coexisting in the montane-subalpine ecotone of the area (Pinus sylvestris L., Pinus uncinata Ram. ex DC., Abies alba Mill., and Betula pendula Roth.) were planted across a gradient of local irradiance levels, and at two different elevations: the ecotone between the montane and the subalpine belt (around $1600 \mathrm{~m}$ ), and at the core of the subalpine belt (around $2000 \mathrm{~m}$ ). We focused our study on the early stages of plant development as these are the most vulnerable to climate alterations (Matías et al. 2011). Our specific objectives were (i) to examine the variation in phenotypic responses to light at plant and organ level among the coexisting species at the ecotone level, (ii) to examine whether these responses changed or were maintained when the species develop above the ecotone, and finally, (iii) to analyze how the water responses of plants to an extreme drought event were modulated by light and elevation. We hypothesized that there would be marked species-specific differences in the phenotypic responses to light, with the shadetolerant species $(A$. alba) showing less variability than the shade-intolerant ones. We also expected that these responses would be affected by the elevation (through the combined effect of temperature stress and drought) and that the species mainly distributed in the montane belt (i.e., B. pendula and $P$. sylvestris) would be more affected by increased elevation than the ones distributed naturally at both altitudes (A. alba and P. uncinata).

\section{Material and methods}

\subsection{Study area and species}

The study included the four most common tree species in the Catalan Pyrenees: Scots pine (P. sylvestris), mountain pine ( $P$. uncinata), silver fir ( $A$. alba), and silver birch (B. pendula). Two of these (P. uncinata and A. alba) are characteristic of the subalpine belt and can be dominant at elevations above $1600-1800 \mathrm{~m}$. P. uncinata is a shade-intolerant conifer that reaches its southern distributional limit in the Pyrenees and is restricted to the subalpine belt (between 1600 and $2300 \mathrm{~m}$ ), constituting most of the Pyrenean treeline. Silver fir (A. $a l b a)$ is usually restricted to humid sites on northfacing, shady slopes between 1400 and $2000 \mathrm{~m}$, where the risk of summer water deficit is lower. In contrast, $P$. sylvestris and B. pendula are more typical in the montane belt, and are rarely found above $2000 \mathrm{~m}$. P. sylvestris is a shade-intolerant species that dominates the montane belt of the Pyrenees, whereas B. pendula is a shade-intolerant pioneer species that usually colonizes disturbed areas between 1000 and $1800 \mathrm{~m}$, but only rarely constitutes the dominant species in the forest. These four species differ widely in their ecological requirements, and range from most $($ rank $=5)$ to least $($ rank $=1)$ shade tolerant following the ranking system developed by Niinemets and Valladares (2006): A. alba $(4.6 \pm 0.06$; mean $\pm \mathrm{SE})$, B. pendula $(2.03 \pm 0.09)$, P. sylvestris $(1.67 \pm 0.33)$, and $P$. uncinata (1.2). Moreover, the drought tolerance ranking order according to the same authors would be $P$. sylvestris (4.34 \pm 0.47$)$; P. uncinata (3.88); B. pendula $(1.85 \pm 0.21)$; and A. alba $(1.81 \pm 0.28)$. Despite their different ecological requirements, these four species are able to coexist in a strip between 1500 and $1800 \mathrm{~m}$, constituting the montanesubalpine ecotone.

The study area was located in the northern slopes of the Serra del Cadi, a mountain range located in the Catalan Pyrenees (NE Spain, Fig. 1). In this area, we established a total of 24 experimental plots at two elevations with contrasting climate: 12 at the ecotone between the montane and the subalpine belt (around $1600 \mathrm{~m}$ ) and 12 at the core of the subalpine belt (around $2000 \mathrm{~m}$ ). The ecotone plots were located at the $P$. sylvestris $-P$. uncinata transition zone and characterized by a mean annual temperature and precipitation of $7.4{ }^{\circ} \mathrm{C}$ and $992 \mathrm{~mm}$ (Ninyerola et al. 2000), whereas the subalpine plots were located upwards in the same valley and under comparable aspect and soil conditions, but colder and 
Fig. 1 Situation of the study area, showing the location of the CadíMoixeró Natural Park and the ecotone and subalpine plots within the park

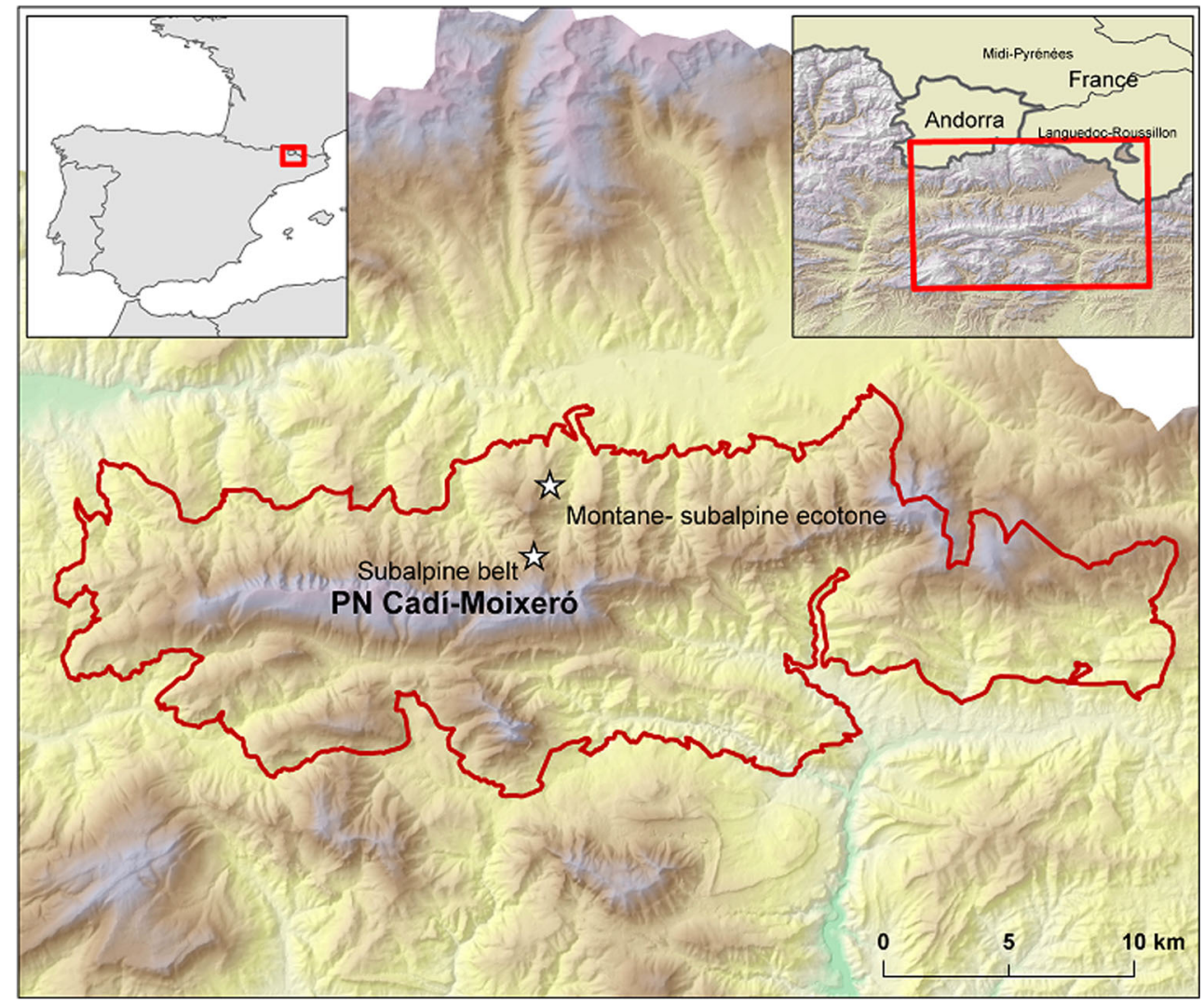

wetter climate (annual temperature $4.9{ }^{\circ} \mathrm{C}$, annual precipitation $1118 \mathrm{~mm}$ ). These plots were established close to the optimum elevation distribution of $P$. uncinata in the Pyrenees and displayed a colder and wetter climate (Table 1). Ground vegetation in both areas was dominated by shrubby species such as box (Buxus sempervirens L.) and common juniper (Juniperus communis L.).

\subsection{Experimental design}

We planted 144 2-year-old seedlings of each of the four studied species during late spring 2008. Due to the presence of wild ungulates and livestock in the study sites, we protected the plants from herbivore damage by an individual protector (90 cm height, $33 \mathrm{~cm}$ diameter) with a mesh net of $20 \times 20 \mathrm{~cm}$ (Nortène, Lille, France). Prior to planting, the seedlings were grown in a local nursery of the Catalan Forest Service (Pobla de Lillet) from local seed sources (i.e., seed source, nursery, and plantation area were all located within the same provenance (Alía et al. 2005)). We distributed seedlings of each species into 12 plots per elevation, with half planted in the forest understory and the other half in naturally occurring gaps, to ensure enough variability in light conditions (which were measured at the individual level, see next section). Seedlings were randomly distributed within each plot, carefully planted to minimize alteration of the microenvironment,
Table 1 Main abiotic and biotic characteristics of the studied stands

\begin{tabular}{lll}
\hline & Montane-subalpine ecotone plots & Subalpine plots \\
\hline Latitude (N)/longitude (E) & $42^{\circ} 19^{\prime} / 1^{\circ} 43^{\prime}$ & $42^{\circ} 18^{\prime} / 1^{\circ} 42^{\prime}$ \\
Elevation (m a.s.l.) & 1550 & 1955 \\
Aspect/slope (\%) & $\mathrm{NE} / 39$ & $\mathrm{NE} / 53$ \\
Bedrock & Limestone & Limestone \\
Mean annual/summer temperature $\left({ }^{\circ} \mathrm{C}\right)$ & $7.4 / 14.8$ & $4.9 / 11.7$ \\
Total annual/summer precipitation $(\mathrm{mm})$ & $992 / 271$ & $1118 / 327$ \\
Length of the growing season $($ days) & 194 & 147 \\
Mean summer maximum temperature $\left({ }^{\circ} \mathrm{C}\right)$ & 21.0 & 17.3 \\
Mean winter minimum temperature $\left({ }^{\circ} \mathrm{C}\right)$ & -3.4 & -4.6 \\
Dominant species & Pinus sylvestris, Betula pendula & Pinus uncinata, Abies alba \\
\hline
\end{tabular}


and placed at a minimum of $1 \mathrm{~m}$ apart from each other to avoid any interaction among them. Each experimental plot measured between 40 and $50 \mathrm{~m}^{2}$, and consisted of a plantation of 24 seedlings (six per species).

\subsection{Climate, local irradiance, and plant water status}

We characterized climate at the two sites via two meteorological stations (one per site), where air temperature at a height of $1 \mathrm{~m}$, belowground soil temperature (at $10 \mathrm{~cm} \mathrm{depth),} \mathrm{and}$ precipitation were continuously measured using ECH2O sensors (Decagon Devices, Pullman, WA, USA). Throughout the study, the seedlings planted at high elevation (subalpine sites) were exposed to lower mean temperatures, more precipitation, a higher Thornthwaite index, and a $20 \%$ shorter growing period than the seedlings at lower elevation (Table 1). During the summer of the last year, a rather warm and dry period (with $60 \%$ less precipitation than the average for the last 10 years, Fig. 2) exposed the vegetation to a significant drought stress that was visually appreciable, even in the adult stand, that showed brownish color in the leaves.
During the fourth growing season, we randomly selected 48 plants per species (two per plot). We measured local irradiance (percentage of transmitted photosynthetic photon flux density, \%PPFD) in July for each plant using two Li-190SA quantum sensors (Li-COR, Lincoln, NE, USA). The measurements were conducted on completely overcast days using the sensors in paired mode, i.e., we placed one of the sensors at the top of each plant and the other in an adjacent open area (see Parent and Messier (1996) for a full description of the method). This allowed us to have quantitative, measured values of local irradiance for each individual plant. We also sampled two fresh leaves of the year per plant (needle fascicles in the case of pines) during the summer. Leaves were collected from the outer part of the seedling, one from the upper third of the plant and the other from the middle third, and stored in moist paper in sealed plastic bags in a cooler, until scanning them in the laboratory within $24 \mathrm{~h}$. We used the CI-202 Portable Laser Area Meter (CID Bio-Sience Inc., WA, USA), to obtain individual leaf area measurements. Leaves were then oven-dried ( $60{ }^{\circ} \mathrm{C}, 2$ days) and weighed, and we computed specific leaf area (SLA) as the ratio between leaf area and oven-dry mass $\left(\mathrm{cm}^{2} \mathrm{~g}^{-1}\right)$.
Fig. 2 Evolution of precipitation (A) and monthly average of the maximum temperatures (B) in the study area over the 4-year study period (2008-2011). Dashed lines and shaded areas indicate mean \pm SD during the last 10 years, whereas solid lines indicate measured values. Data are from the Prat d'Aguiló meteorological station (2138 $\mathrm{m}$ a.s.1.), located less than $1 \mathrm{~km}$ from the high-elevation site. The gray box indicates the extreme drought event and high temperatures during early September 2011 (see text for further details). The arrow indicates the day when measurements of leaf water potential were made
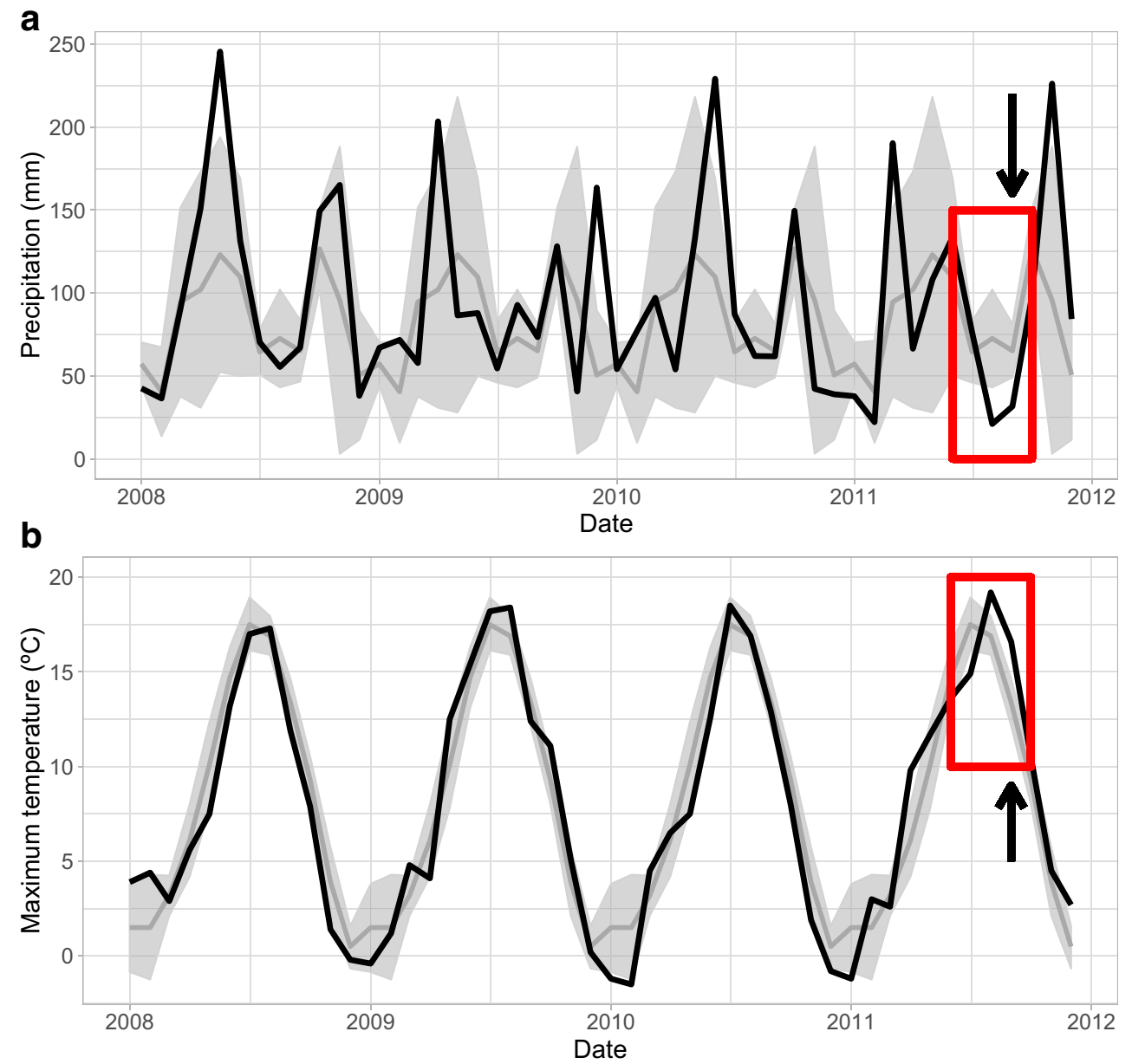
During a particularly dry period occurring at the end of the fourth growing season, we measured midday leaf water potential $\left(\Psi_{\text {midday }}\right)$ in situ on the 48 plants using a pressure chamber (Solfranc Technologies, Vila-Seca, Spain). Following recommendations by PérezHarguindeguy et al. (2013), we collected leaves directly exposed to direct sun to minimize variation due to sunflecks.

\subsection{Plant biomass and leaf traits}

Before planting, we randomly selected 30 plants per species and each plant was separated into leaves, stems, and roots in the laboratory. The roots were washed by placing them under running water over a fine mesh sieve and finger-massaging as needed to remove all the particles (Pérez-Harguindeguy et al. 2013). We then manually removed any big soil particles retained by the sieve. The parts were weighed to the nearest $0.1 \mathrm{mg}$ after oven-drying $\left(60^{\circ} \mathrm{C}, 2\right.$ days), and total biomass, leaf, stem and root biomass, and the root-to-shoot ratio (RSR) calculated.

At the end of the fourth growing season (late October), the 48 plants per species previously used for leaf water potential measurements were harvested, and we calculated total biomass, leaf, stem and root biomass, and the root-to-shoot ratio (RSR) as indicated above. Since at the time of excavation some birch plants had lost a part of their leaves, we did not compute leaf biomass at that time.

\subsection{Data analyses}

We analyzed the effect of light availability (measured for each individual plant) on plant biomass, its components, RSR, specific leaf area, and plant water status. Following the likelihood approach, we compared different models to test our hypotheses: instead of assuming an a priori form of the relationship between dependent variables and predictors, we tested and assessed five model formulations (linear, exponential, power, logarithmic, and MichaelisMenten; Table 3), to account for potential non-linear responses of the dependent variable to light. We compared the results across the four alternative models via the corrected Akaike information criterion ( $\triangle \mathrm{AICc}$, Burnham and Anderson 2002). Each model was also compared to a null model in which there was no effect of the independent variable (light availability). The $R^{2}$ of the regression between observed vs. predicted values provided a measure of the goodness-of-fit of each model, and we deemed a model to be statistically better than another one when $\triangle \mathrm{AICc}>2$.

Once the best formulation for the effect of light availability was selected, we tested whether it was mediated by elevation by comparing the strength of evidence from a model in which parameters were estimated separately for ecotone and subalpine sites, against another model in which all the data were pooled together, and the first model was only retained if it was substantially supported by the data $(\triangle \mathrm{AICc}>2)$.

The maximum likelihood parameter values for all models were estimated using simulated annealing (Goffe et al. 1994) and the asymptotic two-unit support intervals were used to assess the strength of evidence for individual maximum likelihood parameter estimates. All analyses were performed with R 3.2.2 software (R Core Team 2015) and the "likelihood" package ver. 1.7 for $\mathrm{R}$.

\section{Results}

\subsection{Responses to light and elevation at whole-plant level: plant biomass and allocation}

Total biomass at the moment of plantation ranged from 1.3 to $2.5 \mathrm{~g} \mathrm{plant}^{-1}$ (Abies alba and Betula pendula, respectively), with intermediate values for pines ( $P$. sylvestris $2.2 \mathrm{~g} \mathrm{plant}^{-1} ;$. uncinata $\left.2.1 \mathrm{~g} \mathrm{plant}^{-1}\right)$. Four years after planting, total biomass ranged from 3.7 to 4.7 g plant $^{-1}$, with no significant differences in average plant biomass among the species. All the species increased their biomass with light availability, with the exception of $A$. alba (Fig. 3a). We observed no effect of elevation on the response of aboveground biomass to light for $B$. pendula, $P$. sylvestris, and $A$. alba. In contrast, $P$. uncinata showed a greater response in biomass to light at the subalpine belt (Fig. 3b, Table 2). The pattern of carbon allocated to roots along the light gradient differed significantly among species and elevation stages. B. pendula showed the highest overall investment to roots and markedly increased its belowground biomass with light availability, in particular at the montane sites. In contrast, $P$. sylvestris and A. alba showed moderate to null trends, and maintained comparable root biomass under different light availabilities at both stages. Finally, $P$. uncinata plants increased their root biomass in response to irradiance in the subalpine sites but, interestingly, was the only species that decreased root biomass with irradiance at the montane sites (Fig. 3c, Table 2).

The abovementioned differences translated into between-species and between-site variations in the root-to-shoot ratio (RSR) of plants (Fig. 3d). On the one hand, the two species characteristic of the subalpine area (A. alba and P. uncinata) showed a decrease in RSR with light at the montane areas, but a slight increase on the subalpine sites (Fig. 2). On the other hand, the species that are currently found in the 

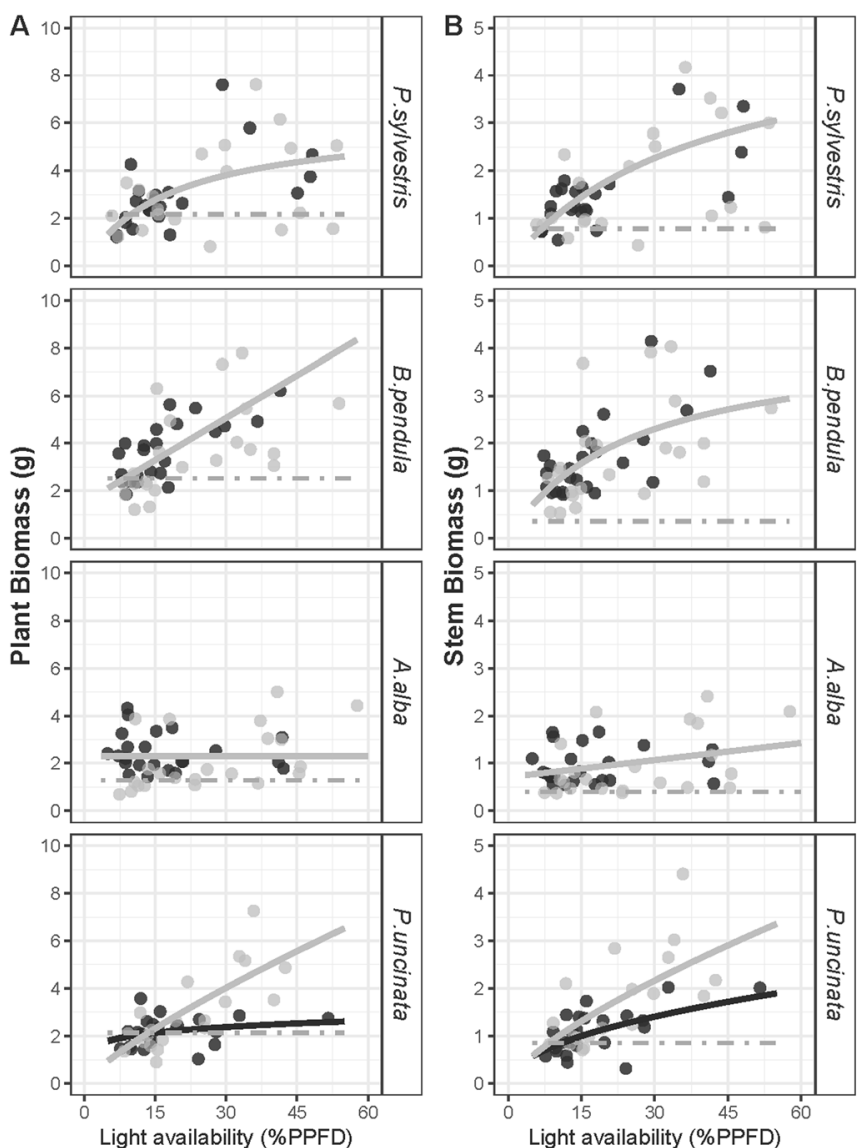

Fig. 3 Predicted variation in plant biomass, stem and root mass fraction, and in root-to-shoot ratio as a function of light availability and elevation for seedlings of the four studied species. Black lines and dots correspond to predicted and observed values, respectively, for seedlings in the montane-subalpine ecotone, whereas gray lines and dots correspond to predicted and observed values in the subalpine belt. When no effect of

montane belt showed either no variations of RSR with light availability (B. pendula) or a decrease in RSR in
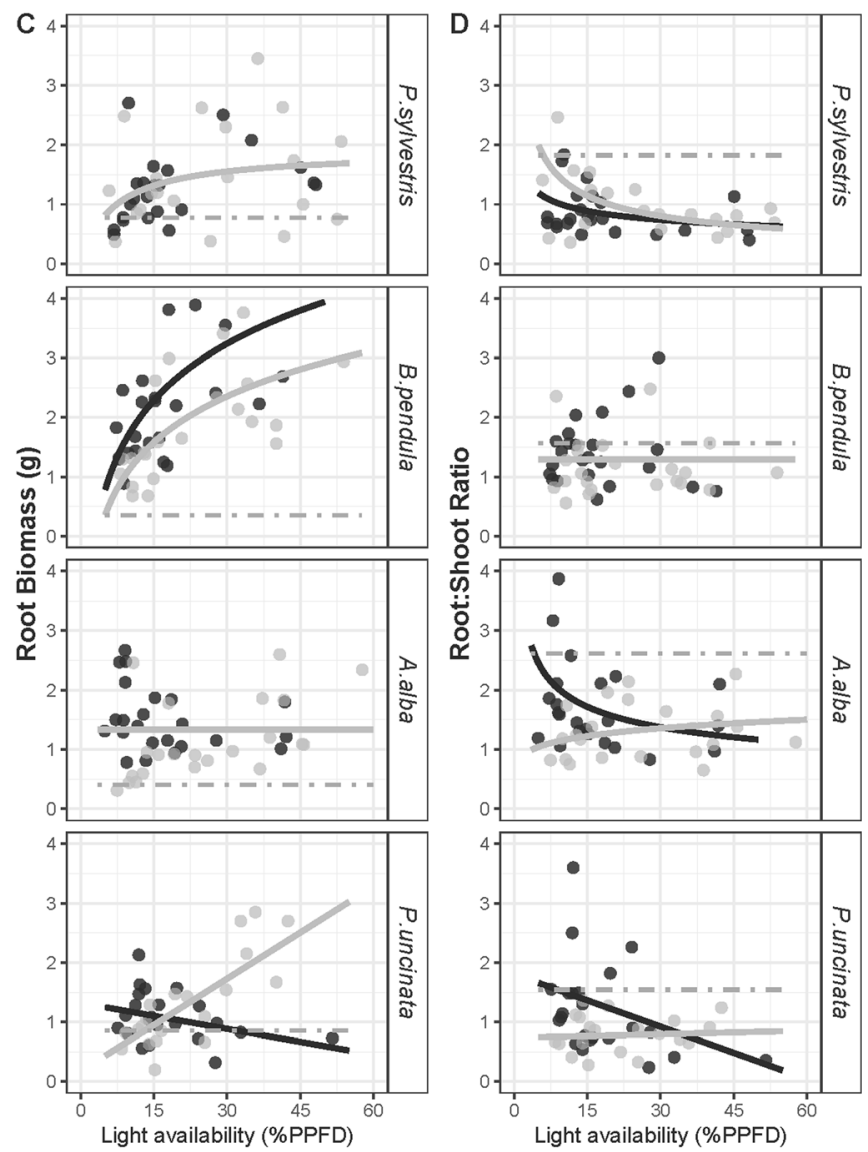

elevation was predicted, data were pooled together and the predicted values are presented in gray. Horizontal lines indicate lack of effect of light availability for that species, and are shown for comparative purposes. Dashed lines represent average values of the response variable at the moment of plantation

response to light increases, particularly when growing in the subalpine sites.

Table 2 Akaike information criterion (AIC) of the models predicting biomass allocation, specific leaf area, and water potential as a function of light availability for seedlings of four tree species planted at two elevations

\begin{tabular}{|c|c|c|c|c|c|c|c|c|}
\hline \multirow[t]{2}{*}{ Species } & \multicolumn{2}{|c|}{ Pinus uncinata } & \multicolumn{2}{|c|}{ Abies alba } & \multicolumn{2}{|c|}{ Pinus sylvestris } & \multicolumn{2}{|c|}{ Betula pendula } \\
\hline & Model & AIC & Model & AIC & Model & AIC & Model & AIC \\
\hline Plant biomass (g) & Pow* & $103.8(-26.6)$ & Null & $137.4(0)$ & MM & $145.5(-23.3)$ & Lin & $163.7(-25.0)$ \\
\hline Stem biomass (g) & Pow* & $67.29(-24.1)$ & Lin & $64.4(-9.9)$ & MM & $97.7(-34.1)$ & MM & $103.7(-24.3)$ \\
\hline Root biomass (g) & Lin* & $50.65(-27.2)$ & Null & $89.4(0)$ & MM & $93.3(-6.8)$ & Lgt* & $109.1(-27.1)$ \\
\hline Root/shoot ratio & Lin* & $69.1(-16.8)$ & Pow* & $84.4(-7.0)$ & Pow* & $43.7(-12.7)$ & Null & $76.0(0)$ \\
\hline $\operatorname{SLA}\left(\mathrm{cm}^{2} \mathrm{~g}^{-1}\right)$ & Null & $315.8(0)$ & Lgt* & $378.1(-8.3)$ & Lgt* & $337.9(-26.2)$ & Pow* & $478.4(-12.3)$ \\
\hline Water potential (MPa) & Null & $315.5(0)$ & Null & $283.7(0)$ & Null & $315.5(0)$ & Pow* & $318.8(-10.8)$ \\
\hline
\end{tabular}

For each species, only the best model (i.e., the one with stronger empirical support) is provided, and the value in brackets is the decrease in AIC compared to the null model (assuming no effect of light availability on the dependent variable). Models flagged with an asterisk indicate stronger empirical support for a model with separate data for both elevations than for pooled data, i.e., an elevation effect

Models are null, null; Lin, linear; Pow, power; Lgt, logarithmic; MM, Michaelis-Menten. The detailed equations for each model and the estimated parameters can be found in Table 3 (Appendix) 


\subsection{Responses to light and elevation at leaf level: specific leaf area and plant water status}

At leaf level, shading resulted in an increase in SLA on A. alba, B. pendula, and P. sylvestris, but failed to affect $P$. uncinata (Table 2). Moreover, the plants of the three former species presented higher SLA values in the subalpine plots, but $P$. uncinata was again the exception (Fig. 4).

Midday water potential values $\left(\Psi_{\min }\right)$ in September were much higher (less negative) for both pine species ( $P$. sylvestris and $P$. uncinata) than for $A$. alba and $B$. pendula (Fig. 5). Conifer species did not show differences in $\Psi_{\min }$ between elevation gradients, with mean values ranging from $-0.63 \mathrm{MPa}(P$. sylvestris, montane sites) to $-2.99 \mathrm{MPa}$ ( $A$. alba, montane sites). In contrast, $B$. pendula presented lower $\Psi_{\min }$ values in the montane sites than in the subalpine ones (Fig. 5). Interestingly, we found $\Psi_{\min }$ in $B$. pendula plants to decrease following a power function in the shaded areas, but this pattern was only observed at the montane sites. Conversely, light availability failed to affect $\Psi_{\min }$ for any of the conifer species (P. uncinata, P. sylvestris, and A. alba).

\section{Discussion}

Our study revealed marked species-specific phenotypic variability of tree seedlings to increasing light (at plantand organ level), and showed that, in most cases, these responses were modulated by the elevation at which the species grew. The use of plants with the same origin (seed source and nursery were within the same provenance) at two different elevations allowed us to assess and reveal the phenotypic component of the allocational and morphological responses of the species to the environment. This phenotypic variability can be a determinant in how young plants respond to environmental changes in the future, and is likely to drive the dynamics of transition zones such as ecotones.

\subsection{Responses to light and elevation at whole-plant level}

The seedlings of the three light-demanding species included in this study ( $B$. pendula, $P$. sylvestris, and $P$. uncinata) increased both stem biomass and total plant biomass with light availability, confirming the critical role played by this factor in the demographic processes of Mediterranean
Fig. 4 Predicted variation in specific leaf area (SLA) as a function of light availability and elevation for seedlings of the four studied species. Black lines and dots correspond to predicted and observed values, respectively, for seedlings in the montanesubalpine ecotone, whereas gray lines and dots correspond to predicted and observed values in the subalpine belt. When no effect of elevation was predicted, data were pooled together and the predicted values are presented in gray. Horizontal lines indicate lack of effect of light availability for that species, and are shown for comparative purposes. Fitted models and parameter values can be found in Table 2 and Table 3 (Appendix), respectively

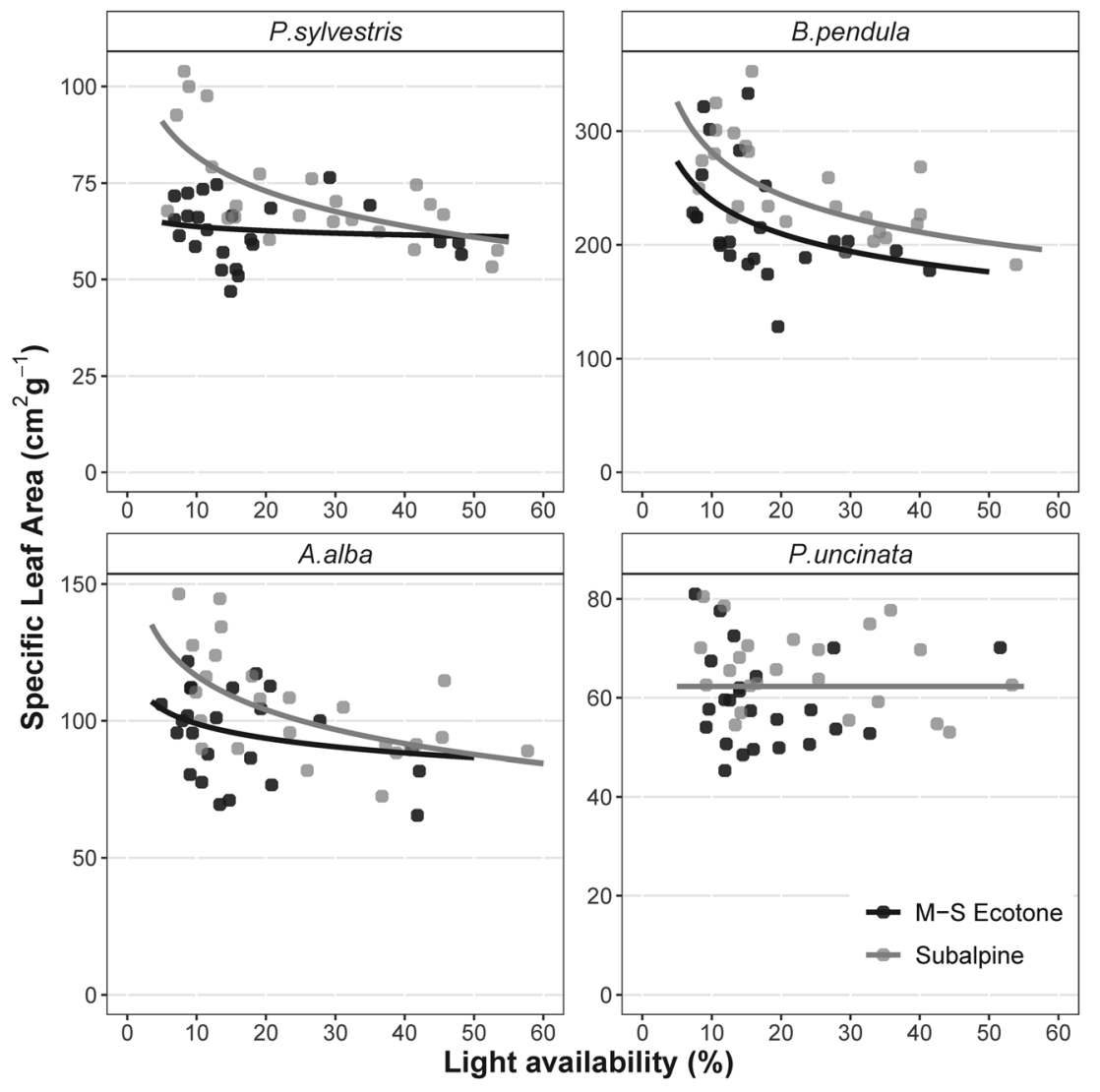


Fig. 5 Predicted variation in water potential $(\mathrm{MPa})$ as a function of light availability and elevation for seedlings of the four studied species. Black lines and dots correspond to predicted and observed values for seedlings in the montane-subalpine ecotone, whereas gray lines and dots correspond to predicted and observed values in the subalpine belt. When no effect of elevation was predicted, data were pooled together and the predicted values are presented in gray. Horizontal lines indicate lack of effect of light availability for that species, and are shown for comparative purposes. Fitted models and parameter values can be found in Table 2 and Table 3 (Appendix), respectively

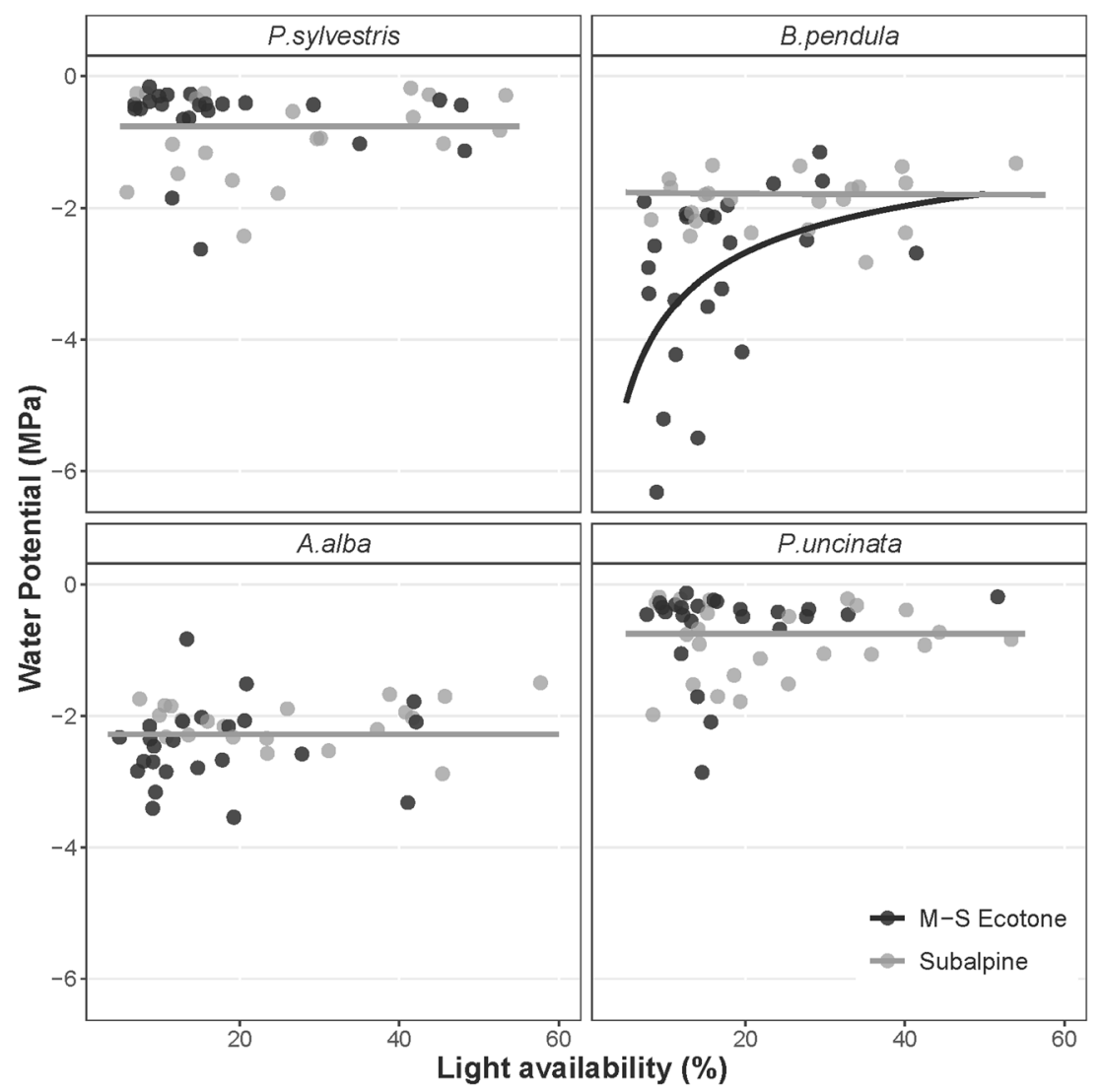

mountain forests (Matías et al. 2011; Ameztegui and Coll 2011). In contrast, the shade-tolerant species (A. alba) showed almost no variability in aboveground and belowground biomass allocation in response to light. These results are in line with a number of studies that have reported overall lower plasticity of shade-tolerant species compared to shade-intolerant ones (Sánchez-Gómez et al. 2006; Valladares et al. 2002a). Interestingly, the two species naturally developing in montane areas $(B$. pendula and $P$. sylvestris) displayed a similar increase in their stem and root biomass with light both at the montanesubalpine ecotone and at the subalpine stage. The other two species-found naturally above the ecotone (i.e., A. alba and P. uncinata) - seemed to adopt a more conservative strategy at low elevation, and showed little growth and higher root-to-shoot ratio when growing below a dense canopy (i.e., under low light availability). Despite the fact that shade adaptation usually implies the opposite allocational trend (i.e., higher carbon allocation to the aboveground organs responsible for capturing light (Mooney 1972; Sack and Grubb 2002; Van Hees and Clerkx 2003)), maintaining high root-to-shoot ratios may allow A. alba and P. uncinata to better face belowground competition from the overstory under particularly intense summer drought episodes. This more conservative strategy was previously observed for these species in a nearby mountain range in relation to height growth (Ameztegui and Coll 2011), and seems to be linked to a trade-off between growth and survival. Our study suggests that Pyrenean subalpine species adopt more conservative allocational strategies under warmer, drier conditions than others in their range.

\subsection{Responses to light and elevation at leaf level}

At leaf level, all the species except $P$. uncinata showed the expected increase in SLA with decreasing light availability (Poorter et al. 2010), which is related to the need to maximize light capture under shade conditions (Planchais and Sinoquet 1998; Curt et al. 2005). In fact, in agreement with Poorter et al. (2012), our results showed generally higher phenotypic variability at organ level rather than at whole-plant level (allocation traits), particularly in the case of A. alba, the most shade-tolerant species (see also Robakowski et al. 2003). P. uncinata seedlings responded differently from the others and upheld constant SLA 
values along the light gradient (except $P$. sylvestris growing in the montane sites). Although the light gradient in P. uncinata was somewhat discontinuous (with only one plot clearly exposed to the sun), this species was also the only one showing no SLA variation between the elevation stages included. A previous study revealed little or no variation in the growth and survival of this species along elevation gradients (Ameztegui and Coll 2013) proving its ability to develop well at both elevation stages. Although no variation of this leaf trait with elevation has already been reported in conifers (Read et al. 2014), we unexpectedly found higher SLA values in the other three studied species when growing at the highest elevation, especially under low light conditions. These findings did not agree with most published literature on the topic, which generally report thicker leaves at high elevation or in a response to low temperatures (see for example Körner et al. 1989; Cordell et al. 1998; Poorter et al. 2010; Bresson et al. 2011). Our results can be explained by the particular gradient of summer drought that is found in Mediterranean mountains. As postulated by Pescador et al. (2015), who found comparable responses to ours in Mediterranean mountain grasslands, drought stress markedly decreases with altitude in these systems. Accordingly, under such conditions, changes in allocational and morphological plant traits within an elevation gradient might not only be mediated by temperature stress, but by the combined effect of both forces. Higher stress in terms of water availability in the lower part of our elevation gradient might partly explain the lower SLA we found for most of the studied species.

At leaf level, the three conifers (A. alba, P. sylvestris, and $P$. uncinata) were able to maintain constant midday water potential during the studied drought period, regardless of the light conditions and the elevation stage at which they developed. The marked isohydric character of these species (they close stomata early during drought to avoid cavitation losses at the expense of carbon assimilation) is probably at the root of this result, and might also explain the poor growth experienced by A. alba and P. uncinata at the lower elevation, where water stress periods during the summer are more frequent (Ameztegui and Coll 2013). Although leaf water potential of $B$. pendula did not vary with light in the subalpine stage, it decreased significantly in the shade at the ecotone level. Higher soil depletion in the understory compared to the gaps, due to competition from mature trees may be the cause of this trend (Valladares and Pearcy 2002b), together with the wellknown low drought tolerance of birch (Niinemets and Valladares 2006), and the reported inability of the species (contrary to A. alba and P. uncinata) to allocate more $\mathrm{C}$ to roots in shade conditions.

\section{Conclusion}

In this study, we found evidence that elevation variation strongly modified species-specific phenotypic responses to light. The effects from elevation mostly occurred at organ level (SLA) for the montane species, but at whole-plant level (allocation traits) for the subalpine species (A. alba and $P$. uncinata). The latter showed a conservative strategy in the absence of light when climatic conditions were warmer and drier than those in their current range, as is expected to happen in the future. Considering the progressive canopy closure that the Pyrenean forests have experienced in the last few decades, the conservative strategy may increase their survival rates, but is likely to put them at a competitive disadvantage against ecologically similar species from the montane belt such as Scots pine (Ameztegui et al. 2015).

We also observed constant or higher SLA in the studied species when they grow at high elevation, a result that differs from most published literature and may be related to the particular climate of Mediterranean mountains. Finally, we found little effect from light and elevation on the water status of the seedlings during a drought event, although the most drought-intolerant species seemed to be more affected by dry conditions in shade than in open microsites. As mentioned in Valladares et al. (2000), caution is needed when interpreting and extrapolating the observed patterns of phenotypic variability to other species and environments in studies conducted with a limited number of these. Further studies involving more species and mountain ranges would be needed to confirm the reported trends.

Funding This study was funded by the Spanish Ministry of Economy and Competitiveness (MINECO) via the projects AGL2012-40039-C02-01 and AGL2015-70425-R. AA was supported by Spanish Government through the "Juan de la Cierva" fellowship program (IJCI-2016-30049). This research is a contribution to the CERCA Programme of the Generalitat de Catalunya.

Data availability The datasets generated and/or analyzed during the current study are available in the Zenodo repository (Coll and Ameztegui 2019). Coll L, Ameztegui A (2019) Elevation modulates the phenotypic responses to light of four co-occurring Pyrenean forest tree species. V1.0. Zenodo. [Dataset]. https://doi.org/10.5281/zenodo.2609013

\section{Compliance with ethical standards}

Conflict of interest The authors declare they have no conflict of interest. 


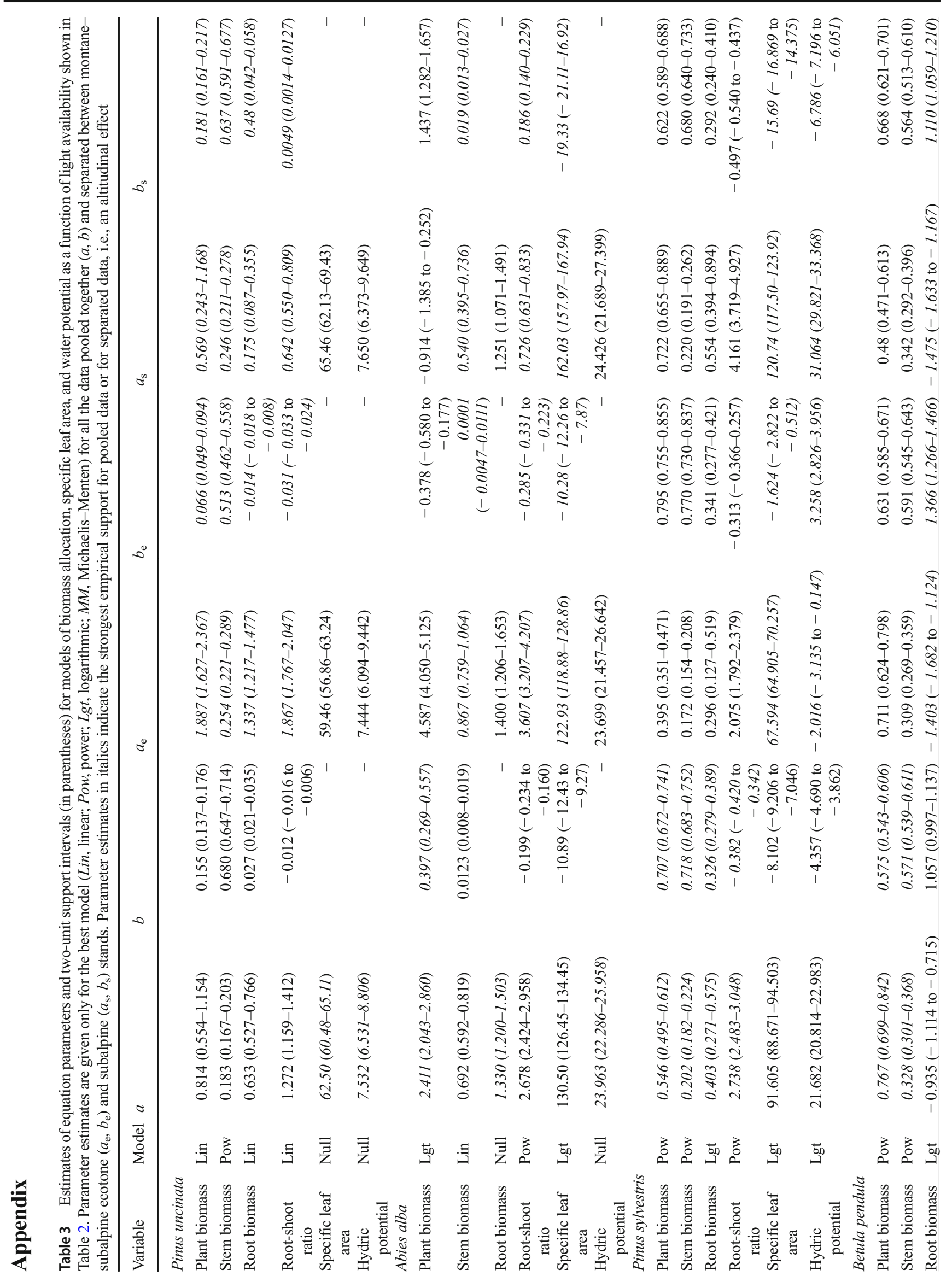




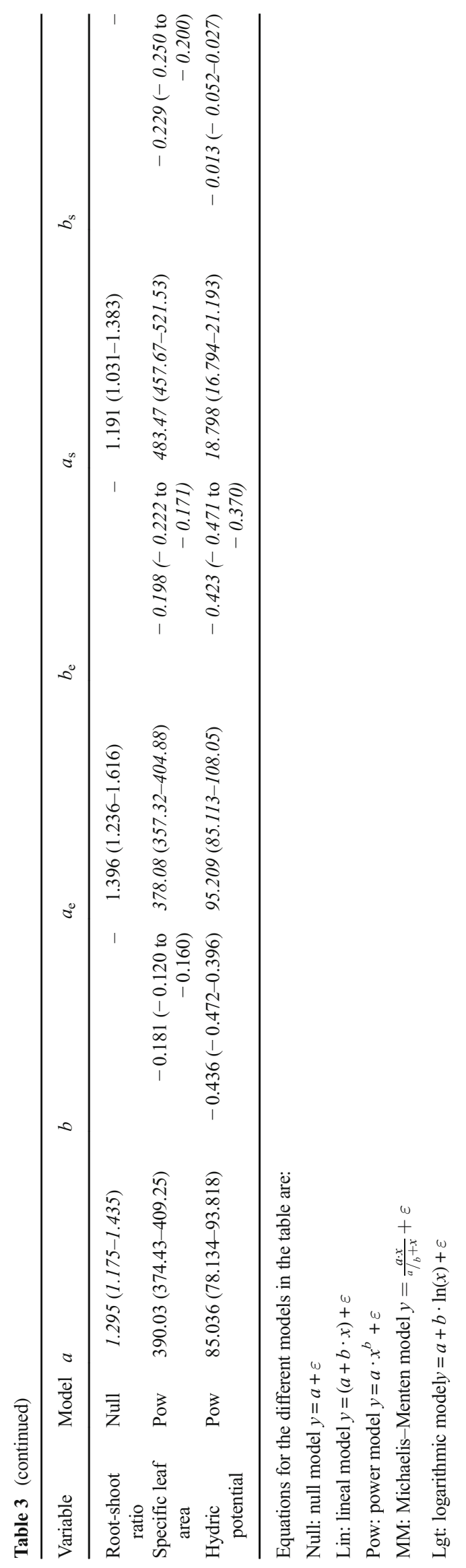




\section{References}

Alía R, Alab N, Agúndez D, Iglesias S (coord.) (2005) Manual para la comercialización y producción de semillas y plantas forestales. Materiales de base y de reproducción. Serie Forestal. DGB. 384 pp. Madrid

Ameztegui A, Coll L (2011) Tree dynamics and coexistence in the montane-subalpine ecotone: the role of different light-induced strategies. J Veg Sci 22:1049-1061

Ameztegui A, Coll L (2013) Unraveling the role of light and biotic interactions on seedling performance of four Pyrenean species under environmental gradients. For Ecol Manag 303:25-34

Ameztegui A, Coll L (2015) Herbivory and seedling establishment in Pyrenean forests: influence of micro- and meso-habitat factors on browsing pressure. For Ecol Manag 342:103-111

Ameztegui A, Brotons L, Coll L (2010) Land-use changes as major drivers of mountain pine (Pinus uncinata Ram.) expansion in the Pyrenees. Glob Ecol Biogeogr 5:632-641

Ameztegui A, Coll L, Messier C (2015) Modelling the effect of climateinduced changes in recruitment and juvenile growth on mixed-forest dynamics: the case of montane-subalpine Pyrenean ecotones. Ecol Model 313:84-93

Benavides R, Rabasa SG, Granda E, Escudero A, Hódar JA, MartínezVilalta J, Rincón AM, Zamora R, Valladares F (2013) Direct and indirect effects of climate on demography and early growth of Pinus sylvestris at the rear edge: changing roles of biotic and abiotic factors. PLoS One 8:e59824

Benavides R, Escudero A, Coll L, Ferrandis P, Gouriveau F, Hódar J, Ogaya R, Rabasa S, Granda E, Santamaría B, Martínez-Vilalta J, Zamora R, Espelta J, Peñuelas J, Valladares F (2015) Survival vs. growth trade-off in early recruitment challenges global warming impacts on Mediterranean mountain trees. Perspect Plant Ecol Evol Syst 17:369-378

Berger S, Sohlke G, Walther G-R, Pott R (2007) Bioclimatic limits and range shifts of cold-hardy evergreen broad-leaved species at their northern distributional limit in Europe. Phytocoenologia 37:523-539

Bodin J, Badeau V, Bruno E, Cluzeau C, Moisselin J-M, Walther G-R, Dupouey J-L (2013) Shifts of forest species along an elevational gradient in Southeast France: climate change or stand maturation? J Veg Sci 24:269-283

Bradshaw AD (1965) Evolutionary significance of phenotypic plasticity in plants. Adv Genet 13:115-155

Bresson CC, Vitasse Y, Kremer A, Delzon S (2011) To what extent is altitudinal variation of functional traits driven by genetic adaptation in European oak and beech? Tree Physiol 31:1164-1174

Burnham KP, Anderson D (2002) Model selection and multi-model inference: a practical information-theoretic approach. Springer-Verlag, New York, USA

Camarero JJ, Gutierrez E (2002) Plant species distribution across two contrasting treeline ecotones in the Spanish Pyrenees. Plant Ecol $162: 247-257$

Camarero JJ, Gutiérrez E, Fortin M-J (2006) Spatial patterns of plant richness across treeline ecotones in the Pyrenees reveal different locations for richness and tree cover boundaries. Glob Ecol Biogeogr 15:182-191

Coll L, Ameztegui A (2019) Elevation modulates the phenotypic responses to light of four co-occurring Pyrenean forest tree species. V1.0. Zenodo. [Dataset]. https://doi.org/10.5281/zenodo.2609013

Cordell S, Goldstein G, Mueller-Dombois D, Webb D, Vitousek PM (1998) Physiological and morphological variation in Metrosideros polymorpha, a dominant Hawaiian tree species, along an altitudinal gradient: role of phenotypic plasticity. Oecologia 113:188-196

Curt T, Coll L, Prévosto B, Balandier P, Kunstler G (2005) Plasticity in growth, biomass allocation and root morphology in beech seedlings as induced by irradiance and herbaceous competition. Ann For Sci 61:1-10
Delagrange S, Messier C, Lechowicz MJ, Dizengremel P (2004) Physiological, morphological and allocational plasticity in understory deciduous trees: importance of plant size and light availability. Tree Physiol 24:775-784

Dinca L, Nita M, Hofgaard A, Alados CL, Broll G, Borz SA, Wertz B, Monteiro AT (2017) Forests dynamics in the montane-alpine boundary: a comparative study in protected European mountains using satellite imagery and climate data. Clim Res 73:97-110

Goffe WL, Ferrier GD, Rogers J (1994) Global optimization of statistical functions with simulated annealing. J Econ 60:65-99. https://doi. org/10.1016/0304-4076(94)90038-8

Hättenschwiler S, Körner C (1995) Responses to recent climate warming of Pinus sylvestris and Pinus cembra within their montane transition zone in the Swiss Alps. J Veg Sci 6:357-368

Hufkens K, Scheunders P, Ceulemans R (2009) Ecotones in vegetation ecology: methodologies and definitions revisited. Ecol Res 24:977-986

Körner C, Neumayer M, Pelaez-Menendez-Rieldl S, Smeets-Scheel A (1989) Functional morphology of mountain plants. Flora 182:353-383

Kupfer JA, Cairns DM (1996) The suitability of montane ecotones as indicators of global climatic change. Prog Phys Geogr 20:253-272

Lenoir J, Gégout J-C, Marquet PA, de Ruffray P, Brisse H (2008) A significant upward shift in plant species optimum elevation during the 20th century. Science 320:1768-1771

Lloret F, Escudero A, Iriondo JM, Martínez-Vilalta J, Valladares F (2012) Extreme climatic events and vegetation: the role of stabilizing processes. Glob Chang Biol 18:797-805

Loehle C (2000) Forest ecotone response to climate change: sensitivity to temperature response functional forms. Can J For Res 30:1632-1645

Loehle C (2003) Competitive displacement of trees in response to environmental change or introduction of exotics. Environ Manag 32: $106-115$

MacArthur RH (1984) Geographical ecology: patterns in the distribution of species. Princeton University Press, Princeton, USA

Matías L, Gómez-Aparicio L, Zamora R, Castro J (2011) Effects of resource availability on plant recruitment at community level: an integrated analysis using structural equation modelling. Perspect Plant Ecol Evol Syst 13:277-285

Mooney H (1972) The carbon balance of plants. Annu Rev Ecol Syst 3: 315-347

Niinemets Ü, Valladares F (2006) Tolerance to shade, drought and waterlogging of temperate northern hemisphere trees and shrubs. Ecol Monogr 76:521-547

Ninyerola M, Pons X, Roure JM (2000) A methodological approach of climatological modelling of air temperature and precipitation through GIS techniques. Int J Climatol 20:1823-1841

Parent S, Messier C (1996) A simple and efficient method to estimate microsite light availability under a forest canopy. Can J For Res 26: $151-154$

Peñuelas J, Boada M (2003) A global change-induced biome shift in the Montseny mountains (NE Spain). Glob Chang Biol 9:131-140

Pérez-Harguindeguy N, Díaz S, Garnier É, Lavorel S, Poorter H, Jaureguiberry P, Bret-Harte MS, Cornwell WK, Craine JM, Gurvich DE, Urcelay C, Veneklaas EJ, Reich PB, Poorter L, Wright IJ, Ray P, Enrico L, Pausas JG, de Vos AC, Buchmann N, Funes G, Quétier F, Hodgson JG, Thompson K, Morgan HD, ter Steege H, Sack L, Blonder B, Poschlod P, Vaieretti MV, Conti G, Staver AC, Aquino S, Cornelissen JHC (2013) New handbook for standardised measurement of plant functional traits worldwide. Aust J Bot 61:167-234

Pescador DS, de Bello F, Valladares F, Escudero A (2015) Plant trait variation along an altitudinal gradient in Mediterranean high mountain grasslands: controlling the species turnover effect. PLoS One 10:e 0118876

Planchais I, Sinoquet H (1998) Foliage determinants of light interception in sunny and shaded branches of Fagus sylvatica (L.). Agric Meteorol 89:241-253 
Poorter H, Niinemets Ü, Walter A, Fiorani F, Schurr U (2010) A method to construct dose-response curves for a wide range of environmental factors and plant traits by means of a meta-analysis of phenotypic data. J Exp Bot 61:2043-2055

Poorter H, Niklas KJ, Reich PB, Oleksyn J, Poot P, Mommer L (2012) Biomass allocation to leaves, stems and roots: meta-analyses of interspecific variation and environmental control. New Phytol 193:30-50

Read QD, Moorhead LC, Swenson NG, Bailey JK, Sanders NJ (2014) Convergent effects of elevation on functional leaf traits within and among species. Funct Ecol 28:37-45

Robakowski P, Montpied P, Dreyer E (2003) Plasticity of morphological and physiological traits in response to different levels of irradiance in seedlings of silver fir (Abies alba Mill). Trees 17:431-441

Sack L, Grubb PJ (2002) The combined impacts of deep shade and drought on the growth and biomass allocation of shade-tolerant woody seedlings. Oecologia 131:175-185

Sánchez-Gómez D, Zavala MA, Valladares F (2006) Seedling survival responses to irradiance are differentially influenced by low-water availability in four tree species of the Iberian cool temperateMediterranean ecotone. Acta Oecol 30:322-332

Valladares F, Pearcy R (2002) Drought can be more critical in the shade than in the sun: a field study of carbon gain and photo-inhibition in a Californian shrub during a dry El Niño year. Plant Cell Environ 25: 749-759
Valladares F, Wright SJ, Lasso E, Kitajima K, Pearcy RW (2000) Plastic phenotypic response to light of 16 congeneric shrubs from a Panamanian rainforest. Ecology 81:1925-1936

Valladares F, Chico JM, Aranda I, Balaguer L, Dizengremel P, Manrique E, Dreyer E (2002) The greater high light seedling tolerance of Quercus robur over Fagus sylvatica is linked to a greater physiological plasticity. Trees 16:395-403

Van der Putten WH, Macel M, Visser ME (2010) Predicting species distribution and abundance responses to climate change: why it is essential to include biotic interactions across trophic levels. Philos Trans R Soc Lond Ser B Biol Sci 365:2025-2034

Van Hees AFM, Clerkx APPM (2003) Shading and root-shoot relations in saplings of silver birch, pedunculate oak and beech. For Ecol Manag 173:439-448

Vernay A, Malagoli P, Fernandez M, Perot T, Ameglio T, Balandier P (2018) Improved Deschampsia cespitosa growth by nitrogen fertilization jeopardizes Quercus petraea regeneration through intensification of competition. Basic Appl Ecol 31:21-32

Publisher's note Springer Nature remains neutral with regard to jurisdictional claims in published maps and institutional affiliations. 